precisely defined, but it was not to be. Cloned natural killer cells were also found to display a wide range of phenotypes and target cell preferences. ${ }^{7}$

The interferons are probably the major common activation pathway for natural killer cells. A brief incubation with interferons rapidly increases natural killer activity in vitro. Purified populations of natural killer cells can also produce interferon after exposure to inducing agents such as poly Ipoly C, BCG, retinoids, and some target cells. ${ }^{8}$ In addition, interleukin 2 ( $\mathrm{T}$ cell growth factor) can directly induce the proliferation of highly purified natural killer populations as well as increase their natural killer activity. ${ }^{9}$ The activity of natural killer cells can be inhibited by prostaglandins, histamine, and lipomodulin. ${ }^{1011}$

Since the first description of natural killer activity in the early 1970s it has been suggested that natural killer cells were an integral part of natural resistance. In conjunction with interferons, which can inhibit viral replication and also recruit cells of the immune system, natural killer cells could play a part in early non-specific attack against virus infected cells. Some evidence that natural killer cells represent a rapidly inducible effector mechanism for eliminating virus infected cells has come from the study of experimental viral infections in animals. ${ }^{1213}$

Among tumour immunologists, renewed interest in natural killer cells has followed a recent report showing a correlation between decreased class 1 antigen expression by lymphoma variants, with increased susceptibility to natural killer lysis. ${ }^{14}$ The authors proposed that this would complement the target specificity of cells of the adaptive immune system in which foreign antigens are recognised in the context of self determinants coded for by the HLA locus. Support for this hypothesis in man comes from studies of the sensitivity of human neuroblastoma cells to lymphocyte mediated cytotoxicity. ${ }^{15}$ Neuroblastoma derived cell lines express very low concentrations of HLA antigens, and these are sensitive to natural killer lysis but not to cytotoxic $T$ lymphocyte mediated cytolysis. Host differences in natural killer effector function may thus be important in the establishment and rate of growth of this type of tumour. In addition, the sensitivity of different types of tumours to $T$ cell or natural killer mediated lysis may have important therapeutic implications.

The study of natural killer cell mediated cytotoxicity has extended into research in rheumatology, maternofetal immunobiology, and particularly transplantation. ${ }^{16}$ The last is of particular interest as natural killer cells have been implicated in the rejection of parental bone marrow graft in hybrid resistance and are implicated as possible effector cells in graft versus host disease. ${ }^{17} 18$

Although the natural killer assay is unlikely yet to become a routine clinical test, therapeutic modulation of natural killer activity may soon become a reality. The natural killer cell may then become more important in clinical medicine.

G CAMBRIDGE

Research Fellow and

Honorary Lecturer in Medicine,

Middlesex Hospital,

London WIP IPG

1 Silver RM, Redelman D, Zvaifler NJ, Naides S. Studies of rheumatoid synovial fluid lymphocytes 1.Evidence for activated natural killer (NK)-like cells. F I mmunol 1982;128:1758-63.

2 Perussia B, Starr S, Abraham S, Fanning V, Trinchieri G. Human natural killer cells analysed by B73.1, a monoclonal antibody blocking Fc receptor functions. 1. Characterisation of the

lymphocyte subset reactive with B73.1. F Immunol 1983;130:2133-41.
3 Lanier LL, Le AM, Phillips JH, et al. Subpopulations of human natural killer cells defined by expression of the Leu-7 (HNK-1) and Leu-11 (NK-15) antigens. F I mmunol 1983;131:1789-97.
4 Horwitz DA, Bakke AC. An Fc receptor bearing, third population of mononuclear cells with cytotoxic and regulatory function. Immunology Today 1984;5:148-53.

5 Robertson M. T-cell receptor: the present state of recognition. Nature 1985;317:768-71.

6 Werkmeister JA, Roder JC, Curry C, Pross. The effect of unphosphorylated and phosphorylated sugar moieties on human and mouse natural killer cell activity: Is there selective inhibition at the level of target recognition and lytic acceptor site? Cell I mmunol 1983;80:172-86.

7 Teh H-S, Yu M. Activation of non-specific killer cells by interlerkin 2-containing supernatants. $\mathcal{F}$ Imomunol 1983;131:1827-33.

8 Baines MG. Natural killer cells. Immunology Today 1986;7(May suppl):22-35.

9 Ythier A, Delmon L, Reinherz E, et al. Proliferation responses of circulating human NK cells: delineation of a unique pathway involving both direct and helper signals. Eur $\mathcal{J}$ Immunol 1985;15:1209-15.

10 Ting CC, Hargrove ME. Activation of natural killer-derived cytotoxic T-lymphocytes. 1. Regulation by macrophages and prostaglandins. $f$ I mmunol 1983;131:1734-41.

11 Hattori T, Hirata F, Hoffman T, et al. Inhibition of human natural killer (NK) activity and antibody dependent cellular cytotoxity (ADCC) by lipomodulin, a phospholipase inhibitory protein. F Immunol 1983;131:662-5.

12 Biron CA, Turgiss LR, Welsh RM. Increase in NK cell number and turnover rate during acute viral infection. $\mathcal{F}$ I mmunol 1983;131:1539-45.

13 Kumagai T, Wong DT, Ogra PL. Development of cell-mediated cyctotoxic activity in the respiratory tract after experimental infection with respiratory virus. Clin Exp Immunol 1985;61:351-9.

14 Karre K, Ljunggren HG, Piontek G, Kiessling R. Selective rejection of $\mathbf{H}-2$ deficient variants

suggests alternative immune defence strategy. Nature 1986;319:675-8.
15 Main EK, Lampson LA, Hart MK, et al. Human neuroblastoma cell lines are susceptible to lysis Main EK, Lampson LA, Hart MK, et al. Human neuroblastoma cell lines are susceptible
by natural killer cells but not by cytotoxic T lymphocytes. I Immunol 1985;135:242-6.

by natural killer cells but not by cytotoxic T lymphocytes. J I mmunol 1985;135:242-6.
16 Herberman RB, ed. NK cells and other natural effector cells. London: Academic Press. 1982.

17 Herberman RB. Natural killer cells and their possible relevance to transplantation biology. Transplantation 1982;34:1-7.

18 Dennert G, Anderson CG, Warner J. Induction of bone marrow allograft rejection and hybrid resistance in nonresponder recipients by antibody: is there evidence for a dual receptor interaction in acute marrow graft rejection? I I mmunol 1986;136:3981-8.

\section{Doctors and the drug industry: too close for comfort}

The drug industry spent $£ 169 \mathrm{~m}$ promoting its products to doctors in 1983, and the estimated expenditure was almost $£ 200 \mathrm{~m}$ for 1985 . That works out at $£ 2500$ for each doctor, but almost $80 \%$ of the expenditure $(£ 160 \mathrm{~m})$ is on general practitioners-over $£ 5000$ is thus spent for each general practitioner. In contrast, the NHS spends about $£ 2 \mathrm{~m}$ refunding expenses incurred by general practitioners attending postgraduate education-less than $£ 70$ for each doctor.

The drug industry does, of course, have a perfect right to promote its products. The 14 years and $£ 100 \mathrm{~m}$ needed on average to produce a new drug mean not only that the company will want to retrieve that money but also that the company is likely to have come to believe strongly in its product: although it might look like "just another $\beta$ blocker" to the doctor, to the company it is a much valued baby and superior to its competitors. When so much is at stake and so much promotional money is being spent ample room exists for the unscrupulous company or doctor to abuse the relationship that has to exist between doctors and the drug industry. But, more worryingly, room also exists for scrupulous doctors to be overinfluenced by a company's promotion and for a company to be overzealous in its promotion.

The Association of the British Pharmaceutical Industry has a (much criticised) code designed to restrain the overzealous company, and now the Royal College of Physicians has produced guidelines that are supposed to make sure that doctors remain thoroughly "professional" in their relationships with drug companies. " The college-almost, I sense, with regret-has desisted from suggesting that doctors do not accept gifts, hospitality, or travelling expenses from drug companies and instead has produced a code full of words like "acceptable," "moderate," "reasonable," "relevant," and "appropriate." The college admits that judging what is acceptable may be difficult, and the truth is that a weekend in 
Spain to hear the benefits of a new benzodiazepine might seem quite "reasonable" to one doctor while a ballpoint pen advertising a diuretic will seem "unreasonable" to another. I think that the college may have underestimated the influence of so much promotion, failed to recognise that scrupulous as well as unscrupoulous doctors are at risk, and produced a code that is castrated by the impossibility of definition.

Examples of excess have been visible to all in the past few years and served to prompt the college's report. The Panorama programme that the report quotes showed us doctors travelling to Venice on the Orient Express to hear news of a new non-steroidal anti-inflammatory drug, and a recent story in the newspapers detailed an ex-drug company representative's allegations of how doctors were bribed to enter patients into a scientifically bogus trial. ${ }^{2}$ Oddly these sporadic reports in the media usually depict the drug companies rather than the doctors as the "baddies." The college's report, however, contains stories in which (anonymous) doctors are clearly the baddies. Many doctors, it seems, write to drug companies asking for funds to pay for foreign trips, and "one doctor even stated that unless his request was granted he would stop prescribing the company's products." Another group of doctors refused to attend a film unless it was "shown with a meal organised at a restaurant of their choice." On another occasion "physicians who all lived in one NHS region" went to a drug company meeting on a "Mediterranean island," which, as the college observes in restrained prose, "could not have the advantage of convenience."

So are a few doctors abusing the system and spoiling it for others, or are these practices widespread? The college report gives no idea of scale but implies that it is small. Mediterranean island trips are not, I suspect, common, but excessive hospitality is. For instance, the code of practice of the ABPI states that "entertainment or hospitality offered . . . should always be secondary to the main purpose of the meeting." Yet I have spoken to many meetings myself where my small "turn" (which could only in the loosest sense be described as educational) has clearly been secondary to the wining and dining offered by drug companies.

One point is thus that the immoderate may be more common than the college recognises. Another point is that the college may underestimate the effect of drug company promotion on doctors' thinking and prescribing. Scientific evidence on this issue is hard to come by, but such massive expenditure by the drug companies must have substantial influence. It is a similar argument to that over promotion of tobacco and alcohol; only in this case doctors tend to be on the other side. Of course, you could not find a doctor who says that he prescribes a drug because of the lunches given to him by the company, but it is equally hard to find a consumer who buys a certain brand of rum because of the tropical beaches used to advertise it. Yet marketing data, most of which are rarely made available, show that such promotions do influence sales of their products. Some general practitioners have suggested that the powerful influence of drug companies may be their main source of postgraduate education, ${ }^{3}$ and bias - as every researcher knows-is subtle and pervasive.
Many of the committee's recommendations are hamstrung by the difficulty of definition. One inspired suggestion is that: "a useful criterion of acceptability may be "Would you be willing to have these arrangements generally known?", This useful concept acknowledges the important point that $\widehat{\Omega}$ independence is in the eye of the beholder-whether you are $\overline{\bar{F}}$ seen to be independent is more important than whether you ${ }_{\mathbb{D}}$ are, or think you are, independent. And at least to the Guardian reading public writing your prescriptions with ae drug company pen and drinking even vin ordinaire at drug company expense are sure signs of dependence. The com- $\stackrel{5}{\stackrel{9}{9}}$ mittee does say that it regrets that refreshment at meetings is $\frac{}{\mathrm{C}}$ so often sponsored by pharmaceutical companies and says $\frac{\bar{\sigma}}{\bar{\omega}}$ that as a regular practice it "degrades" the profession. It calls $\frac{\bar{\Phi}}{\nabla}$ on the Department of Health and Social Security to en- $\varrho$ courage health authorities to contribute to the support of कs meetings, but it seems to forget that doctors could pay for $\vec{\circ}$ themselves. In the absence of a drug company to pay for $\overrightarrow{\vec{\omega}}$ lunch most doctors still eat.

The committee does better with its recommendations on윽 controlling the content of meetings between doctors and drug company representatives. It recommends against ad hoc meetings and suggests that they should take place only ${ }^{\circ}$ by appointment. It also recommends that at promotional N meetings there should always be present an expert capable of $\bullet$ independently assessing the claims of the company. $A$ or further possibility would have been to suggest a clear 은 system-like that operating in many Swedish hospitals-of $\exists$ determining in advance the scientific and educational value $O$ of what is to be presented. ${ }^{4}$ The aim would be steadily to raise $\stackrel{\odot}{\circ}$ the quality of such meetings. Many drug companies would welcome such a scheme: they do not like dealing in an $\vec{\theta}$ unseemly trade of ballpoint pens and Italian red wine-they $\mathscr{\odot}$ want to make their case and be off.

The college has done well to raise this issue of theo relationship between doctors and drug companies, which until now has been discussed more in the lay media than by doctors themselves; and it has produced some useful $\stackrel{\circ}{\varnothing}$ recommendations. But I believe that this report should be $\stackrel{2}{\overrightarrow{2}}$ seen as the beginning rather than the end of a debate on how $\frac{3}{3}$ doctors relate to drug companies. A tougher and more? specific code-even one with teeth-will eventually be needed.

\section{Assistant Editor,}

RICHARD SMITH

AMS

1 Royal College of Physicians. The relationship between physicians and the pharmaceutical industry. London: RCP, 1986.

2 Erlichman J. "GPs had cash for unethical testing" allegation. Guardian 1986 September 10:1.

3 Worthen DB. Prescribing influences: an overview. British fournal of Medical Education 1973;7: N

4 Smith R. Doctors and the drug industry in Sweden. Br Med $\mathcal{J}$ 1985;290:448.

\section{Correction}

Hypoplastic anaemia and parvovirus infection

We regret that an error occurred in the title of this article by Dr D P Bentley (4 October, p 836)-hyperplastic was wrongly printed when hypoplastic was meant. 